\title{
Molecular detection of filarioid worms in dogs in Nigeria, West Africa
}

\author{
Joshua Kamani ${ }^{\text {* }}$, Alicia Rojas ${ }^{2}$, Emmanuel Msheliza $^{1}$, Mike Shand ${ }^{3}$, \\ Shimon Harrus ${ }^{2}$, and Gad Baneth ${ }^{2}$
}

'Parasitology Division, National Veterinary Research Institute (NVRI), PMB 01 Vom, Plateau State, Nigeria

${ }^{2}$ Koret School of Veterinary Medicine, The Hebrew University of Jerusalem, Rehovot, Israel

${ }^{3}$ Institute of Biodiversity, Animal Health \& Comparative Medicine (IBAHCM), and School of Geographical and Earth Sciences, University of Glasgow, Glasgow, UK

\section{KAMANI, J., A. ROJAS, E. MSHELIZA, M. SHAND, S. HARRUS, G. BANETH: Molecular detection of filarioid worms in dogs in Nigeria, West Africa. Vet. arhiv 89, 821-830, 2019.}

\section{ABSTRACT}

The filarioid worm Dirofilaria repens has long been reported in dogs in Nigeria. Recent studies however, did not only report increased prevalence of $D$. repens but also the presence of Dirofilaria immitis. The classical diagnostic methods used in these studies have low sensitivity. Therefore, we screened 197 canine blood samples from seven states in Nigeria, using a highly sensitive and specific High Resolution Melt Real Time PCR and sequencing, to determine the prevalence and species of filarial worms infecting Nigerian dogs. Only one $(0.5 \%)$ of the 197 samples screened was positive and showed a melt curve similar to Acanthocheilonema reconditum. Nevertheless, the sequence of this positive sample had only $94 \%$ similarity to its first GenBank match, a $A$. reconditum (JF461460.1). This could be a new filarioid species or a variant of an existing species and deserves further investigation. The low prevalence reported herein is in discrepancy with previous reports that showed the frequent presence of canine filariasis in Nigeria. A large scale survey is needed of filarioids infecting dogs in Nigeria, using highly sensitive and specific methods, to identify the present species and provide a baseline data on their national prevalence and geographic distribution.

Key words: Dirofilaria spp.; HRM RT-PCR; diagnosis; guidelines; dogs; Nigeria

\section{Introduction}

Dirofilaria immitis and Dirofilaria repens are mosquito-borne pathogenic parasites of dogs and other canids (McCALL et al., 2008). A number of mosquito species belonging to a wide range of genera, including Culex, Aedes, Ochlerotatus, Anopheles, Armigeres and

\footnotetext{
${ }^{*}$ Corresponding author:

Joshua Kamani (DVM, MVSc, PhD) Parasitology Division, National Veterinary Research Institute (NVRI), PMB 01 Vom, Plateau State, Nigeria, Phone: +234 703551 7715; E-mail: mshelizakj@gmail.com
} 
Mansonia are incriminated in the transmission of D. immitis and D. repens (CANCRINI et al., 1995, ANYANWU et al., 2000). Acanthocheilonema reconditum, another filarioid worm of dogs, has global distribution (KORKEJIAN and EDESON, 1978; MINNAAR and KRECEK, 2001) and is mostly found in the subcutaneous tissues of dogs. It is transmitted by fleas, Ctenocephalides felis or Ctenocephalides canis (FARNELL and FAULKNER, 1978; LINDEMANN et al., 1983) or lice: Heterodoxus spiniger or Linognathus setosus. Dirofilaria immitis and D. repens are considered zoonotic parasites because they have been found on several occasions in the heart, major vessels, connective and subcutaneous tissues and lungs of humans (FAUST et al., 1941; ABADIE et al., 1965; GOLDSTEIN and SMITH, 1985; PAMPIGLIONE and RIVASI, 2000).

Several diagnostic methods for detection of the adult worms, circulating microfilariae or parasite antigens have been developed over the years, with varying sensitivity and limitations (KNOTT, 1939; GRIEVE et al., 1983; PERIBANEZ et al., 2001; FISCHER et al., 2002; GENCHI et al., 2005; 2007; McCALL et al., 2008; CIOCAN et al., 2010, LIOTTA et al., 2013). However, most of these methods lack the ability to discriminate between the various filarioid worms, hence the need to combine two or more methods before confirmatory diagnosis. To overcome this, highly sensitive and specific molecular approaches have been developed that allow easy discrimination of the main canine filarial nematodes (MAR et al., 2002; CASIRAGHI et al., 2006; RISHNIW et al., 2006; THANCHOMNANG et al., 2010; WONGKAMCHAI et al., 2012; ROJAS et al., 2015).

Infections with filarioid worms have been reported in dogs in Nigeria, either as case reports or in survey studies, by several research groups (SCHILLHORN VAN VEEN, 1974; SCHILLHORN VAN VEEN and BLOTKAMP, 1975; ODUYE and DIPEOLU, 1976; IDOWU et al., 1977; BOBADE et al., 1981; KAMALU, 1991; UCHE and ODUNZE, 1988; ANYANWU et al., 1996; AJADI et al., 2011; ABAH, 2015; UGOCHUCKWU et al., 2016; OGBAJE and DANJUMA, 2016).

In the early studies, from 1974 to 2010 , D. repens was reported most, with up to $9.2 \%$ prevalence (SCHILLHORN and BLOTKAMP, 1975). In contrast, later studies, from 2011 to 2017 , reported mainly $D$. immitis, with the highest prevalence of $15 \%$ in Zaria, Nigeria (ABAH, 2015). In all the previous reports, the diagnosis relied on the morphological features of adult worms or microscopic identification of circulating microfilariae using conventional techniques such as stained blood smears, direct wet smears or a modified Knott's technique. These diagnostic methods are not only labor-intensive and potentially misleading, but also have low sensitivity and require highly experienced personnel to interpret the results. Furthermore, it is difficult to detect multiple infections with more than one species of filarial worms or accurately differentiate between the microfilariae of the various species, which leads to false results (SCOLES and KAMBHAMPATI, 1995; MAR et al., 2002; IRWIN and JEFFERIES, 2004; RISHNIW et al., 2006). A retrospective 
review of previous dirofilariasis reports in Nigeria raised some questions: has there been an increase in prevalence over the years; has there been a switch in the prevalence of $D$. repens and $D$. immitis, and what could be responsible for these changes? In an attempt to address these questions, we used a highly sensitive and specific high resolution melt (HRM) real-time PCR to screen canine blood samples from four out of the six geopolitical regions of Nigeria, for the presence of filarioid worms.

\section{Materials and methods}

Ethics statement. The study protocol was approved by the Institutional Ethical Committee on Animal Use and Care (AUCC), National Veterinary Research Institute (NVRI) Vom, Nigeria, permit number AEC/03/21/15. The animals were treated in a humane manner and in accordance with authorizations and guidelines for Ethical Conduct in the Care and Use of Nonhuman Animals in Research of the American Psychological Association (APA) for use by scientists working with nonhuman animals.

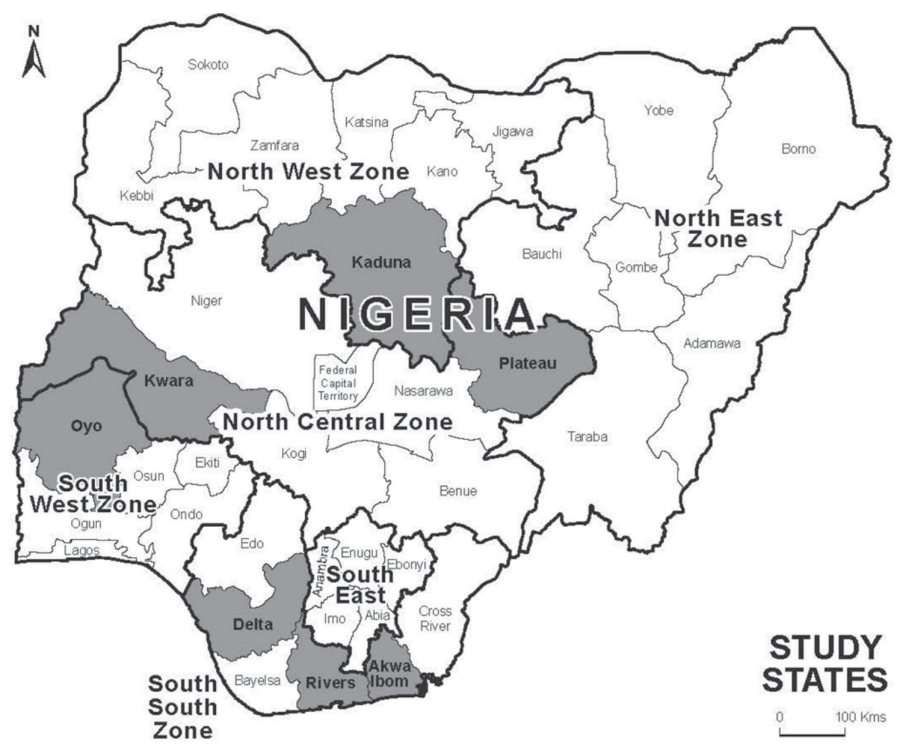

Fig. 1. Map of Nigeria showing study areas

Study area and sampling of dogs. Blood samples for this study were collected from dogs in seven states, namely: Akwa Ibom $(n=47)$, Delta $(n=28)$, Kaduna $(n=11)$, Kwara $(n=3)$, Plateau $(n=150)$, Oyo $(n=41)$ and Rivers $(n=17)$, located in four out of the six geopolitical regions of Nigeria (Fig. 1). In total, 297 dogs from private or government veterinary hospitals were sampled between August 2011 and July 2013. The 
purpose of the study was explained to the dog owners, and their oral consent was sought before the dogs were sampled. In addition, demographic data (age, sex, and breed) and clinical signs were recorded for each dog. Five $\mathrm{mL}$ of blood were collected from the cephalic vein of each dog into sterile EDTA tubes and kept in cold boxes or at $4^{\circ} \mathrm{C}$ until arrival at the Protozoology laboratory, NVRI, Vom. Samples were kept at $-80^{\circ} \mathrm{C}$ in the laboratory until their shipment to the Koret School of Veterinary Medicine Rehovot, The Hebrew University of Jerusalem in Israel for molecular analyses.

DNA extraction. DNA was extracted from blood samples using the Illustra blood genomic Prep Mini Spin kit (GE Healthcare UK Limited) according to the manufacturer's instructions. The concentration and quality of DNA were determined by measuring the absorbance at 230, 260 and $280 \mathrm{~nm}$ (A260) with a NanoVue Spectrophotometer (GE Healthcare, UK Limited).

HRM real-time PCR for detection of filarioid-DNA in dog blood samples. A high resolution melt (HRM) real-time PCR was performed according to the protocol of WONGKAMCHAI et al. (2012) with the modifications described by ROJAS et al. (2015). The PCR primers (5'-TTTAAACCGAAAAAATATTGACTGAC-3' and 5'AAAAACTAAACAATCAT ACATGTGCC-3') target approximately a 115 bp partial sequence of the mitochondrial $12 \mathrm{~S}$ gene of canine and feline filarioids (WONGKAMCHAI et al., 2012). Each reaction contained $3 \mu \mathrm{L}$ of DNA sample diluted in a final volume of $20 \mu \mathrm{L}$, with $10 \mu \mathrm{L}$ of Maxima Hot Start PCR Master Mix 2x (Thermo Fisher Scientific Inc., Surrey, UK), $4.4 \mu \mathrm{L}$ sterile PCR grade water, (Biological Industries, Kibbutz BeitHaemek, Israel), $0.6 \mu \mathrm{L}$ of SYTO-9 (Invitrogen, California, USA) and $1 \mu \mathrm{L}$ of each primer at $500 \mathrm{nM}$. The real-time PCR program consisted of an initial hold of 4 min at $95{ }^{\circ} \mathrm{C}$ followed by 50 cycles of $5 \mathrm{~s}$ at $95^{\circ} \mathrm{C}, 15 \mathrm{~s}$ at $58^{\circ} \mathrm{C}$ and $10 \mathrm{~s}$ at $72^{\circ} \mathrm{C}$. The melt curve was constructed from $60^{\circ} \mathrm{C}$ to $95^{\circ} \mathrm{C}$ with increments of $1{ }^{\circ} \mathrm{C} / \mathrm{sec}$, followed by a hybridization step from 90 to $50{ }^{\circ} \mathrm{C}$. Finally, an HRM curve was measured from 70 to $85^{\circ} \mathrm{C}$ at $0.1{ }^{\circ} \mathrm{C} /$ sec increments. Reactions were performed with a Rotor Gene $6000^{\mathrm{TM}}$ cycler (Corbet, Sydney, AU). For each PCR run, a non-template control (NTC) with PCR-grade water and DNA from a laboratory-bred pathogen-free dog blood sample were included. For positive controls, DNA extracted from blood samples with D. immitis and A. reconditum from heavily infected dogs from Costa Rica, and DNA from D. repens-positive blood samples from Israel were used.

Sequencing. The positive DNA sample was purified (Exo-SAP, NEB; New England Biolabs, Inc., Ipswich, MA) and sequenced at the Center for Genomics Technologies, Hebrew University of Jerusalem, Israel. The quality of the DNA sequence was evaluated and all ambiguities were cleaned using the Chromas Lite software version 2.01 (Technelysium pty Ltd) and compared for similarity to sequences deposited in GenBank, 
using the BLAST program hosted by the National Center for Biotechnology Information (NCBI), National Institutes of Health, Bethesda, MD (www.ncbi.nlm.nih.gov/BLAST).

\section{Results and discussion}

During this study, 197 dog samples were examined out of the total of 297 samples from seven states in Nigeria. The majority $(125 ; 63.5 \%)$ of the samples analyzed were from the north central region (Plateau State 122; 61.9\%; Kwara State 3; 1.3\%), followed by $41(20.8 \%$ ) samples from the south-south region (Akwa Ibom State 16; 8.1\%; Delta State $14 ; 7.1 \%$; Rivers State $11 ; 5.6 \%$ ). The remainder of the samples were from the north-west (Kaduna State 8; 4.1\%) and south west (Oyo State 23; 17.7\%) regions of Nigeria (Fig 1). Samples could not be collected from the north-east and south-east regions due to security and logistic constraints, respectively. Three of the regions (north-west, north-central and south-west) covered in this study had had previous reports of canine filariasis (SCHILLHORN VAN VEEN and BLOTKAMP, 1975; BOBADE et al., 1981; ANYANWU et al., 1996; AJADI et al., 2011; ABAH, 2015; OGBAJE and DANJUMA, 2016), while there were no published reports from the south-south region (Fig 1). Of the dogs examined, $89(45.2 \%)$ belonged to a local (Nigerian) breed, 78 (39.6\%) belonged to pure foreign breeds, $21(10.7 \%)$ were cross-breeds, while no information on breed was available for $9(4.6 \%)$ of the dogs. Male dogs accounted for $37.6 \%(n=74)$; females for $54.8 \%(n=108)$, and there was no information on sex for $15(7.6 \%)$ of the samples analyzed. The age ranges of the study population were $0-6$ months, $24.4 \%(\mathrm{n}=48) ; 7-12$ months, $18.3 \%(\mathrm{n}=36)$; $13-24$ months, $27.9 \%(\mathrm{n}=55) ; 25-36$ months, $10.7 \%(\mathrm{n}=21)$; $>36$ months, $13.2 \%(\mathrm{n}=26)$, while no information on age was available for $11(5.6 \%)$ dogs.

Of all the samples screened in this study using the HRM real-time PCR, only one sample was amplified with a Tm similar to the $A$. reconditum positive control in the PCR run. The sequence obtained was 94\% identical to A. reconditum (GenBank accession number JF461460.1). Therefore, the molecular analysis of the remaining 100 samples was discontinued.

The overall prevalence of $0.5 \%$ obtained in this study is similar to the $0.4 \%$ prevalence reported in dogs from south-west Nigeria (IDOWU et al., 1977) but lower than other previous reports from several regions of Nigeria (SCHILLHORN VAN VEEN 1974; SCHILLHORN VAN VEEN and BLOTKAMP, 1975; BOBADE et al., 1981; UCHE and ODUNZE, 1988; ANYANWU et al., 1996; AJADI et al., 2011; ABAH, 2015; OGBAJE and DANJUMA, 2016; UGOCHUCKWU et al., 2016). The low prevalence obtained from the use of a highly sensitive HRM real-time PCR in this study was surprising considering the fact that earlier studies based on classical methods had detected and reported a higher prevalence in Nigerian dogs. It is noteworthy to consider the fact that 
the classical methods used in the previous studies have inherent limitations in their ability to detect occult infections and to identify the species of the filarioid worms accurately, and are therefore prone to give false results (GENCHI et al., 2007).

Thus far no other study of canine filariasis in Nigeria has employed a molecular approach. Although there was a positive result in one of our samples, the sequence obtained had only $94 \%$ homology to an $A$. reconditum sequence deposited in the GenBank, suggesting that it could be a new filarioid species or a variant of $A$. reconditum. This finding underscores the fact that as sensitive as PCR is, amplification alone, either in a conventional or a real-time reaction, is not always sufficient for species identification. Running a PCR program that targets a larger gene fragment, coupled with further downstream analyses of amplicons, such as sequencing and comparison with GenBank sequence deposits and phylogenetic analyses, is recommended. Sometimes targeting one gene of the organism for amplification and sequencing may not conclusively resolve the problem, hence the need for multiple reactions and sequencing before final confirmation of the results. The low prevalence $(0.5 \%)$ of canine filariasis using the HRM RT-PCR technique reported here may raise questions on the reliability of the PCR program and the integrity of the canine DNA used in the study, considering the high prevalence reported by earlier studies using less sensitive methods. However, the PCR program used here was designed specifically for detection of canine filarioid worms and had been also used previously to detect and differentiate filarioid worms with high specificity (WONGKAMCHAI et al., 2012; ROJAS et al., 2015). In addition, the DNA used in this study was evaluated for quality on a NanoVue Spectrophotometer (GE Healthcare, UK Limited). Furthermore, most $(144 ; 73.1 \%)$ of the DNA screened in this study had been tested earlier for other vector-borne parasites, with good results (KAMANI et al., 2013). Thus, the integrity of the DNA and the PCR program had been already verified earlier. Therefore, a future large scale survey, using at least two diagnostic methods of high sensitivity and specificity, including PCR and a sequencing approach to screen dogs across Nigeria, to provide reliable data on the prevalence of canine filariasis, is worth consideration.

\section{Limitations of this study}

The research design and sample size were the major drawbacks to this study. Most of the samples screened were obtained on the basis of convenience sampling; hence we could not obtain blood samples from dogs in some of the areas where there had been previous reports of canine filariasis. Similarly, the numbers of samples screened from some of the states were too few to enable us to draw conclusions on the status of canine filarioids in those areas. Furthermore, screening blood samples alone will fail to detect filarioid worms that localize in the connective tissue without developing microfilaremia 
J. Kamani et al.: Molecular detection of filarioid worms in dogs in Nigeria, West Africa

in the canine host, e.g. occult infections. Nevertheless, this study highlights the need for a mapped large scale survey of canine filariasis in Nigeria in order to determine the dominant species and their geographical distribution.

\section{Conclusion}

The use of a highly sensitive and specific HRM-TR PCR detected a low prevalence of $0.5 \%$ DNA of filarioid worms in Nigerian dogs. The sequence of the positive sample was $94 \%$ identical to $A$. reconditum as its first GenBank match. More studies are needed to confirm the real identity of this filarioid worm infecting dogs in Nigeria.

\section{Funding}

This study did not receive any specific grant from funding agencies in the public, commercial, or not-for-profit sectors

\section{Conflicts of interest}

The authors have no competing interest.

\section{References}

ABADIE, H., J.C. SWARTZWELDER, R. L. HOLMAN (1965): A human case of Dirofilaria immitis infection. Am. J. Trop. Med. Hyg. 14, 117-118.

ABAH, H. O. (2015): Prevalence of Dirofilaria imitis in dogs in Zaria. Msc thesis Ahmadu Bello University Zaria, Nigeria. Accessed online at kubani.abu.edu.ng on $20^{\text {th }}$ December 2017

AJADI, R. A., T. O. OMOBOWALE, O. O. IGADO, J. O. ADEJINMI, O. A. ADEDOKUN, H. O. NOTTIDGE (2011): Dirofilaria immitis infection in a three year old doberman. Folia Vet. 55, 103-106.

ANYANWU, I. N., R. I. S. AGBEDE, O. J. AJANUSI, J. U. UMOH, N. D. G. IBRAHIM (2000): The incrimination of Aedes (Stegomyia) aegypti as the vector of Dirofilaria repens in Nigeria. Vet. Parasitol. 92, 319-327

ANYANWU, I. N., J. U. UMOH, V. C. OGBOGU, E. S. ESSIEN, M. GALADIMA, D. A. Y. ADAWA, A. Z. Hassan (1996): Canine filariasis in Zaria, Nigeria. Afri. J. Med. Med. Sci. 25, 323-326.

BOBADE, P. A., P. B OJEBUOBOH, O. AKINBOADE (1981): A case of canine filariasis due to Dipetalonema reconditum (Grassi 1889) in Nigeria. Journ. Small. Anim. Pract. 22, 201-206.

CANCRINI, G., M. PIETROBELLI, D. I. FRANGIPANE, A. F. REGALBONO, M. P. TAMPIERI, A. DELLA TORRE (1995): Development of Dirofilaria and Setaria nematodes in Aedes albopictus. Parasitologia 37, 141-145.

CASIRAGHI, M., C. BAZZOCCHI, M. MORTARINO, E, OTTINA, C. GENCHI, C (2006): A simple molecular method for discriminating common filarial nematodes of dogs (Canis familiaris). Vet. Parasitol. 141, 368-372. 
CIOCAN, R., G. DĂRĂBUŞ, V. IGNA (2010): Morphometric study of microfilariae of Dirofilaria spp. on dogs. Bul. UASVM, Vet. Med. 67, 1843-5270.

FARNELL, D. R., D. R. FAULKNER (1978): Prepatent period of Dipetalonema reconditum in experimentally-infected dogs. J. Parasitol. 64, 565-567.

FAUST, E. C., E. P. THOMAS, J. JONES (1941): Discovery of human heartworm infection in New Orleans. Parasitol. 27, 115-122.

FISCHER, P., H. WILBOWO, S. PISCHKE, P. RUCKERT, E. LIEBAU, I. S. ISMID, T. SUPALI (2002): PCR based detection and identification of the filarial parasite Brugia timori from Alor Island, Indonesia. Ann. Trop. Med. Parasitol. 96, 809-821.

GENCHI, C., L. VENCO, M. GENCHI (2007): Guidelines for the laboratory diagnosis of canine and feline Dirofilaria infections. In: Dirofilaria imitis and D. repens in Dogs and Cats and Human Infections (Genchi, C., L. Rinaldi, G. Cringoli, Eds.) Rolando Editore, Naples, 137-143.

GENCHI, C., L. VENCO, M. GENCHI (2005): Guideline for the laboratory diagnosis of canine and feline Dirofilaria infections. Mappe Parassitologiche 8, 139-144.

GOLDSTEIN, J. D., D. R. SMITH (1985): Dirofilaria immitis in a portal shunt. Hum. Pathol. 16, 1172-1173.

GRIEVE, R. B., J. B. LOK, L. T. GLICKMAN (1983): Epidermiology of canine heartworm infection. Epidemiol. Rev. 5, 220-246.

IDOWU, L., E. D. OKON, O. O. DIPEOLU (1977): A three year analysis of parasitic diseases of dogs and cats in Ibadan. Bull. Anim. Health Prod. Afr. 25, 166-170.

IRWIN, P. J., R. JEFFERIES (2004): Arthropod-transmitted diseases of companion animals in Southeast Asia. Trends Parasitol. 20, 27-34.

KAMALU, B. P (1991): Canine filariasis caused by Dirofilaria repens in southeastern Nigeria. Vet. Parasitol. 40, 335-338.

KAMANI, J., G. BANETH, K. Y. MUMCUOGLU, N. E. WAZIRI, O. EYAL, Y. GUTHMANN, S. HARRUS (2013): Molecular detection and characterization of tick-borne pathogens in dogs and ticks from Nigeria. PLoS Negl. Trop. Dis. 7, e2108.

DOI:10.1371/journal.pntd.0002108

KNOTT, J. (1939): A method for making microfilarial survey on day blood. Med. Hyg. 33, 191-196.

KORKEJIAN, A., J. F. B. EDESON (1978): Studies on naturally occurring filarial infections in dogs in Lebanon. Am. J. Trop. Med. Parasitol. 72, 65-78.

LINDEMANN, B. A., T. L. EVANS, J.W. McCall (1983): Clinical responses of dogs to experimentally induced Dipetalonema reconditum infection. American Journal of Vet. Res. 44, 2170-2172.

LIOTTA, J. L., G. K. SANDHU, M. RISHNIUS, D. D. BOWMAN (2013): Differentiation of the microfilariae of Dirofilaria immitis and D. repens in stained blood film. J. Parasitol. 99, 421-425. DOI: $10.1645 / 12-10.1$ 
J. Kamani et al.: Molecular detection of filarioid worms in dogs in Nigeria, West Africa

MAR, P., I. YAN, G. CHANG, A. C. FEI (2002): Specific polymerase chain reaction for differential diagnosis of Dirofilaria immitis and Dipetalonema reconditum using primers derived from transcribed spacer region 2 (ITS - 2). Vet. Parasitol. 106, 243-252.

McCALL, J. W., C. GENCHI, L. H. KRAMER, J. GUERRERO, L. VENCO (2008): Heartworm disease in animals and humans. Adv. Parasitol. 66, 193-285.

MINNAAR, W. N., R. C. KRECEK (2001): Helminths in dogs belonging to people in a resourcelimited urban community in Gauteng, South Africa. Onderstepoort J. Vet. Res. 68, 111-117.

ODUYE, O. O., O. O. DIPEOLU (1976): Blood parasites of dogs in Ibadan. J. Small. Anim. Pract. 17, 331-337.

OGBAJE, C. I., A. DANJUMA (2016): Prevalence and risk factors associated with Dirofilaria immitis infection in dogs in Makurdi, Benue State, Nigeria. J. Adv. Vet. Anim. Res. 3, 338-344.

PAMPIGLIONE, S., F. RIVASI (2000): Human dirofilariasis due to Dirofilaria (Nochtiella) repens: an update of world literature from 1995 to 2000. Parassitologia 42, 231-254.

PERIBANEZ, M. A., J. LUCIENTES, S. ARCE, M. MORAleS, J. A. CASTILlo, M. J. GRACIA (2001): Histochemical differentiation of Dirofilaria immitis, Dirofilaria repens and Acanthocheilonema dracunculoides microfilariae by staining with a commercial kit, Leucognost-SP (R). Vet. Parasitol. 102, 173-175.

RISHNIW, M., S. C. BARR, K. W. SIMPSON, M. F. FRONGILLO, M. FRANZ, J. L. DOMINGUEZ ALPIZAR (2006): Discrimination between six species of canine microfilariae by a single polymerase chain reaction. Vet. Parasitol. 135, 303-314.

ROJAS, A., D. ROJAS, V. M. MONTENEGRO, G. BANETH (2015): Detection of Dirofilaria immitis and other arthropod-borne filarioids by an HRM real-time qPCR, blood-concentrating techniques and a serological assay in dogs from Costa Rica. Parasit. Vectors 8, 170.

DOI 10.1186/s13071-015-0783-8.

SCHILLHORN VAN VEEN, T. (1974): Filariasis in domestic animals in northern Nigeria and its relation to human health. In: Parasitic Zoonoses (Soulsby, E. J. I., Ed.) Clinical and Experimental Studies. Academic Press, New York, pp. 287-293.

SCHILLHORN VAN VEEN, T., J. BLOTKAMP (1975): Filarial infection of dogs in the Zaria area. A microfilarial survey. Am. J. Trop. Med. Parasitol., 69, 517-518.

SCOLES, G. A., S. KAMBHAMPATI (1995): Polymerase chain reaction-based method for the detection of canine heartworm (Filariodea: Onchocercidae) in mosquitoes (Diptera: Culicoidae) and vertebrate hosts. J. Med. Entomol. 32, 864-869.

THANCHOMNANG, T., P. M. INTAPAN, V. LULITANOND, S. SANGMANEEDET, S. CHUNGPIVAT, P. TAWEETHAVONSAWAT, W. CHOOCHOTE, W. MALEEWONG (2010): Rapid detection of Dirofilaria immitis in mosquito vectors and dogs using a real-time fluorescence resonance energy transfer PCR and melting curve analysis Vet. Parasitol. 168, 255-260.

UCHE, U. E., E. B. K. ODUNZE (1988): Incidence of microfilaria in dogs in Southern Nigeria. Revue Élev. Méd. Vét. Pays Trop. 41, 375-379. 
UGOCHUKWU, C. I. I., N. OMEKAM, E. I. UGOCHUKWU (2016): Incidence of Dirofilaria immitis in dogs presented at University of Nigeria, Nsukka Veterinary Teaching Hospital using wet smear and buffy coat techniques. Asian Pacific J. Trop. Dis. 6, 627-630.

WONGKAMCHAI, S., N. MONKONG, P. MAHANNOL, P. TAWEETHAVONSAWAT, S. LOYMAK, S. FOONGLADDA (2012): Rapid detection and identification of Brugia malayi, B. pahangi, and Dirofilaria immitis by high-resolution melting assay. Vector Borne Zoonot. 13, 31- 36 .

KAMANI, J., A. ROJAS, E. MSHELIZA, M. SHAND, S. HARRUS, G. BANETH: Molekularni dokaz filarija u pasa u Nigeriji, zapadna Afrika. Vet. arhiv 89, 821-830, 2019.

\section{SAŽETAK}

O parazitu Dirofilaria repens u pasa u Nigeriji odavno postoje podaci. Novija istraživanja, međutim, ne pokazuju samo povećanu prevalenciju $D$. repens nego i prisutnost $D$. immitis. Klasične dijagnostičke metode primijenjene u ovom istraživanju imaju nisku osjetljivost. Stoga smo ispitali 197 uzoraka pseće krvi iz sedam pokrajina u Nigeriji koristeći se visokoosjetljivom i visokospecifičnom metodom High Resolution Melt Real Time PCR i sekvenciranjem kako bismo odredili prevalenciju i vrste filarija koje invadiraju pse u Nigeriji. Samo je jedan (0,5 \%) od 197 uzoraka bio pozitivan i pokazao je krivulju sličnu krivulji za parazita Acanthocheilonema reconditum. Sekvencija tog pozitivnog uzorka imala je samo $94 \%$ sličnosti s prvom podudarnom sekvencijom iz banke gena, A. reconditum (JF461460.1). To bi mogla biti nova vrsta filarija ili varijanta postojećih vrsta i zahtijeva daljnja istraživanja. Opisana niska prevalencija u ovome radu odstupa od prijašnjih izvješća koja pokazuju čest nalaz psećih filarija u Nigeriji. Kako bi se dokazale postojeće vrste i pružili referentni podaci o prevalenciji i zemljopisnoj raširenosti filarija u pasa u Nigeriji, potrebno je provesti opsežnija istraživanja.

Ključne riječi: Dirofilaria spp.; HRM RT-PCR; dijagnostika; smjernice; psi; Nigerija 